\title{
Peripheral blood mononuclear cells and regulatory T cells in acute viral hepatitis
}

\author{
V BARNABA, E TAMBURRINI, V LAGHI, R CAUDA, M LEVRERO, \\ G RUOCCO, L ORTONA, AND F BALSANO
}

From the Istituto di I Clinica Medica, Università di Roma 'La Sapienza', Rome, Italy, and Istituto di Malattie Infettive, Università Cattolica, Rome, Italy

SUMmARY During acute viral hepatitis, we observed a significant decrease in OKT4/OKT8 ratio with a significant increase in the OKT8 positive subset in acute type B and non-A-non-B hepatitis. This altered ratio persisted in type B for a long time until HBsAg antibody became detectable, while it soon returned to normal in type $A$ and non-A-non-B hepatitis. In the majority of acute hepatitis the altered ratio is because of an increase and not to a decrease in the whole $\mathrm{T}$ cell population, as described in chronic HBV infection. The number of HNK-1 positive cells remained raised during the recovery phase of type $B$ and non-A-non-B hepatitis, a finding consistent with the hypothesis that NK cells play a role in the host defence against $B$ and non-A-non-B virus infections. Serum $\beta_{2}$-microglobulin concentrations were increased only in acute hepatitis $B$ and non-A-non-B where immunological mechanisms are suspected to be involved, and showed a good correlation with the population of activated OKIa positive cells.

A number of viruses affect the liver as a part of systemic infections - for example, cytomegalovirus, Epstein Barr virus and yellow fever virus - but the term 'hepatitis viruses' usually refers to HAV (hepatitis A virus), HBV (hepatitis B virus) and non-A-non-B agents. Hepatitis A virus seems to be directly cytopathic for infected hepatocytes and never leads to chronic infection. Hepatitis B virus infection may result in either acute or chronic infection. As HBV is not directly cytopathic for infected hepatocytes, host determined immunologic response is considered a likely pathogenetic mechanism in this disease. ${ }^{1}$ The cell mediated immune response to component antigens of the virus results in the lysis of infected hepatocytes in acute and chronic active hepatitis while only a poor or absent response has been shown in chronic persistent hepatitis and in healthy carriers. ${ }^{2}$ This immune response to the virus may be regulated by the immunoregulatory network. The importance of a balance between inducer and suppressor cells in maintaining immune homeostasis has recently been illustrated and abnormalities in these $\mathrm{T}$ cell subsets have been associated with a number of human diseases. ${ }^{3}$ Recently, the development of monoclonal

Address for correspondence: Dr Vincenzo Barnaba, Via Antonelli 41, 00197 Rome, Italy.

Received for publication 15 August 1984 antibodies against $T$ cell subsets has allowed the demonstration of a decreased helper to suppressor cell ratio, because of an increase in suppressor cell concentrations, during acute type $\mathrm{B}$ hepatitis. ${ }^{4}$ When this ratio returns to normal the $\mathrm{HBsAg}$ is cleared and anti-HBs becomes detectable. Similar abnormalities have been found in HBsAg positive chronic hepatitis. ${ }^{45}$ We have used similar techniques to analyse peripheral blood lymphocytes and $T$ cell subsets in patients with acute type $A, B$, and non-A-non-B hepatitis.

Moreover, $\beta_{2}$-microglobulin $\left(\beta_{2} \mathrm{~m}\right)$ was measured in serum samples from our patients at or after the disease onset. This protein has a molecular weight of 12000 and is non-covalently linked to glycoproteins bearing Class I histocompatibility antigens on almost all cell membranes, especially lymphocytes. It may be considered a potential marker for evaluating $\mathrm{T}$ cell activation in vivo. ${ }^{6}$ Recently, several reports ${ }^{7}$ have suggested that $\beta_{2} \mathrm{~m}$ is a marker of activity in immune mediated liver diseases and might be useful in the study of pathogenic mechanisms of liver injury.

\section{Methods}

PATIENTS AND CONTROL DONORS

Forty five ( 25 men and 20 women) patients affected 
by acute viral hepatitis (five with type $A, 31$ with type $B$ and nine with type non-A-non-B) were studied. Ages ranged from 16-68 years. serologic studies of HBV and HAV markers (HBsAg, anti$\mathrm{HBs}$, anti-HBc, $\mathrm{HBeAg}$, anti-HBe, anti-HAV IgM, anti-HAV total) and $\beta_{2} \mathrm{~m}$ were carried out by radioimmunoassay using commercially available reagent kits (AUSRIA II, AUSAB, CORAB, HBe/anti-HBe, HAVAB-M, HAVAB, Abbott Laboratories; Phadabas $\beta_{2}$ MICROTEST, Pharmacia). HBV-DNA polymerase (DNA-P) activity was measured ir patients affected by acute type $B$ hepatitis, using the method originally described by Kaplan et al ${ }^{9}$ and modified by Zanetti et al. ${ }^{10}$ Patients negative for $\mathrm{HBV}$ and $\mathrm{HAV}$ markers and for antibodies to cytomegalovirus and Epstein Barr virus were considered to have non-Anon-B hepatitis. Table 1 shows the changes in ALT and serum viral markers in the patients studied. Peripheral blood mononuclear cell populations, $T$ cell subsets and $\beta_{2} \mathrm{~m}$ levels were evaluated in different phases of the disease. Eighteen patients (three with type A, 11 with type B and four with type non-A-non-B) were studied within 20 days from the onset of symptoms, 19 patients (two with type A, 12 with type B, five with type non-A-non-B) were studied within 21-50 days. In addition, eight patients were evaluated in the recovery phase of acute type B hepatitis (three within 51-90 days from the onset of symptoms and five within 91-120 days). The control population consisted of 22 healthy subjects for characterisation of the $T$ cell subpopulations and of 15 healthy individuals for the serum $\beta_{2}$ m levels, matched for age and sex, with no history of viral hepatitis and negative for all HAV and HBV serological markers. Serum creatinine levels were within the normal range in all controls and patients.

ISOLATION OF CELLS

Peripheral blood mononuclear cells were isolated from heparinised venous blood through FicollHypaque density gradient centrifugation ${ }^{11}$ and washed three times in RPMI 1640 (Eurobio, Paris) supplemented with $5 \%$ heat-inactivated fetal calf serum (FCS) (Gibco, GI, NY), $25 \mathrm{mM}$ Hepes (Gibco), $100 \mathrm{U} / \mathrm{ml}$ penicillin and $100 \mu \mathrm{g} / \mathrm{ml}$ streptomycin (Eurobio).

\section{LYMPHOCYTE SURFACE PHENOTYPE}

A suspension of $5 \times 10^{6}$ cells per millilitre was made. The lymphocyte surface phenotype was established by indirect immunofluorescence, as previously described in detail, ${ }^{5}$ using well characterised monoclonal antibodies (Ortho-Labs and Becton Dickinson) against all peripheral blood $\mathrm{T}$ cells (OKT3), T helper cells (OKT4), $\mathrm{T}$ suppressorcytotoxic cells (OKT8), Ia antigens (OKIa), monocytes (OKM1), K and NK cells (Leu 7). At least 300 cells were counted for each sample. Quantitation of peripheral blood mononuclear cell subsets was done under code to avoid the introduction of subjective bias.

\section{STATISTICAL ANALYSIS}

Data analysis was performed by means of Student's $t$ test for unpaired data to compare patients' and controls' peripheral blood mononuclear cells subpopulation mean values, and the $\chi^{2}$ test to evaluate the relationships between PMBC and serum ALT, $\gamma$-globulins and $\beta_{2} \mathrm{~m}$ concentrations. Results are expressed as means \pm SEM.

Table 1 Serum alanine aminotransferase $(A L T)$ and serum viral markers in each group of acute viral hepatitis patients

\begin{tabular}{|c|c|c|c|c|c|c|c|}
\hline Patient group & No & $\begin{array}{l}A L T^{*} \\
(I U / l)\end{array}$ & $H B s$ Ag $^{\dagger}$ & $\mathrm{HBeAg} \dagger$ & $D N A-P+$ & anti-HBs ${ }^{\dagger}$ & anti-HAV+IgM+ \\
\hline \multicolumn{8}{|l|}{$\mathrm{HBV}$} \\
\hline $0-20$ days & 11 & $1450 \pm 245$ & $100 \%$ & $45 \%$ & $82 \%$ & 1 & 1 \\
\hline 21-50 days & 12 & $460 \pm 228$ & $100 \%$ & $45 \%$ & $25 \%$ & I & 1 \\
\hline 51-90 days & 3 & $85 \pm 29$ & $66 \%$ & 1 & 1 & 1 & I \\
\hline $91-120$ days & 5 & $32 \pm 4$ & 1 & 1 & 1 & $100 \%$ & 1 \\
\hline \multicolumn{8}{|l|}{ HAV } \\
\hline $0-20$ days & 3 & $180 \pm 89$ & 1 & 1 & 1 & 1 & $100 \%$ \\
\hline $21-50$ days & 5 & $38 \pm 2$ & 1 & 1 & 1 & 1 & $100 \%$ \\
\hline \multicolumn{8}{|l|}{ non-A-non-B } \\
\hline $0-20$ days & 4 & $157 \pm 27$ & 1 & 1 & 1 & 1 & 1 \\
\hline $21-50$ days & 5 & $95 \pm 30$ & 1 & 1 & I & 1 & 1 \\
\hline
\end{tabular}

HBsAg: Hepatitis B surface antigen; HBeAg: hepatitis B 'e' antigen; DNA-P: DNA polymerase activity; anti-HBs: antibody to HBsAg; anti-HAV IgM: antibody to hepatitis A antigen of IgM class.

*: normal range $<50 \mathrm{IU} / 1$; data are expresed as mean \pm 1 SEM

$\dagger$ : figures indicate the percentages of positive patients in each group; vertical bars are equivalent to $0 \%$. 
Results

OKT4/OKT8 ratio was significantly reduced in early phases of all acute viral hepatitis groups, as compared with normal controls (Fig. 1). This ratio soon returned to normal in type $A$ and non-A-non-B hepatitis coincident with improvement in transaminase concentrations, while it was persistently low in type B hepatitis during the entire period of $\mathrm{HBs}$ antigenaemia. No difference in OKT4/OKT8 ratio was demonstrated in $\mathrm{HBsAg}$ positive patients between DNA-P positive and DNA-P negative cases, or between $\mathrm{HBeAg}$ positive and $\mathrm{HBeAg}$ negative patients (Table 2). Analysis of peripheral blood mononuclear cells subpopulations (Table 3) showed no significant difference in OKT4 positive cells and an absolute increase in OKT8, OKIa, OKM1 and HNK-1 positive subsets in the early phase of type B and non-A-non-B hepatitis. The concentrations of OKT8 positive cells soon declined to only slight increases in those patients with non-A-non-B hepatitis along with the decrease in transaminase concentrations. In type $\mathrm{B}$ hepatitis OKT8 positive cells, as well as OKT3, OKIa, OKM1 and HNK-1 positive cells remained abnormally high along with $\mathrm{HBsAg}$ persistence and returned to normal when anti-HBs became detectable; only HNK-1 cells remained persistently raised. Patients with type $A$ hepatitis showed no significant difference in lymphocyte populations and in $T$ cell subsets although a transient expansion in OKT8 positive subsets and a reduction of OKT4 positive cell concentrations were observed. No correlation was observed between ALT or serum $\gamma$-globulins and T cell subpopulations.

Increased serum $\beta_{2} \mathrm{~m}$ concentrations were observed during acute type $\mathrm{B}$ and non-A-non-B

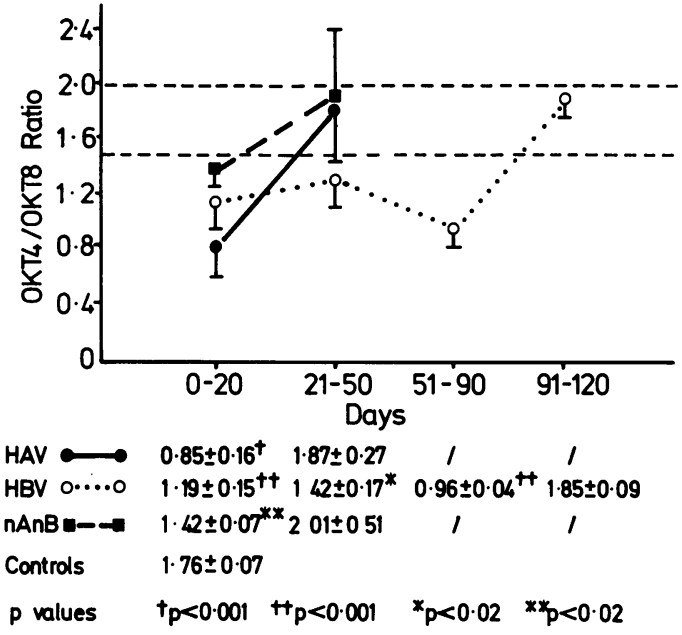

Fig. 1 OKT4/OKT8 ratios as a function of time after clinical onset in patients with acute viral hepatitis of different aetiology.

hepatitis but never in type $\mathrm{A}$. These high levels soon returned to normal in non-A-non-B hepatitis while they remained persistently abnormal in type $\mathrm{B}$ during the period of HBs antigenaemia (Fig. 2). No correlation was detectable between ALT or $\gamma$ globulins and $\beta_{2} \mathrm{~m}$, while a significant correlation was found between serum $\beta_{2} \mathrm{~m}$ and OKIa positive cell percentages $(p<0 \cdot 025)$ (Fig. 3$)$.

\section{Discussion}

During acute viral hepatitis we observed a significant decrease in the inducer to suppressor/cyto-

Table 2 Mononuclear cell subsets in acute type $B$ viral hepatitis patients grouped according to $\mathrm{HBe} \mathrm{Ag}$ and DNA polymerase status

\begin{tabular}{|c|c|c|c|c|c|c|c|c|c|c|c|c|c|}
\hline & \multicolumn{2}{|c|}{$O K T 3$} & \multicolumn{2}{|c|}{ OKT4 } & \multicolumn{2}{|c|}{ OKT8 } & \multicolumn{2}{|c|}{ OKIa } & \multicolumn{2}{|c|}{$O K M 1$} & \multicolumn{2}{|c|}{$H N K-1$} & \multirow[t]{2}{*}{ Ratio } \\
\hline & No & $\%$ & No & $\%$ & No & $\%$ & No & $\%$ & No & $\%$ & No & $\%$ & \\
\hline $\mathrm{HBeAg}+\mathrm{ve}(6)$ & $\begin{array}{r}1426 \\
\pm 148\end{array}$ & $\begin{array}{r}63 \cdot 7 \\
\pm 2 \cdot 1\end{array}$ & $\begin{array}{r}805 \\
+129\end{array}$ & $\begin{array}{r}35 \cdot 1 \\
\pm 2.8\end{array}$ & $\begin{array}{r}613 \\
\pm 46\end{array}$ & $\begin{array}{r}28 \cdot 1 \\
\pm 2 \cdot 0\end{array}$ & $\begin{array}{r}281 \\
\pm 38\end{array}$ & $\begin{array}{r}13.1 \\
\pm 1.9\end{array}$ & $\begin{array}{r}325 \\
\pm 56\end{array}$ & $\begin{array}{r}15.0 \\
\pm 3.7\end{array}$ & $\begin{array}{r}246 \\
\pm 65\end{array}$ & $\begin{array}{r}10.9 \\
\pm 2.4\end{array}$ & $\begin{array}{r}1.31 \\
\pm 0 \cdot 18\end{array}$ \\
\hline HBeAg-ve (16) & $\begin{array}{r}1431 \\
\pm 108\end{array}$ & $\begin{array}{r}68.4 \\
\pm 1.6\end{array}$ & $\begin{array}{r}829 \\
\pm 96\end{array}$ & $\begin{array}{r}37.4 \\
\pm 1.8\end{array}$ & $\begin{array}{r}617 \\
\pm 24\end{array}$ & $\begin{array}{r}31.9 \\
\pm 2.3\end{array}$ & $\begin{array}{r}345 \\
\pm 40\end{array}$ & $\begin{array}{r}16 \cdot 7 \\
\pm 2 \cdot 2\end{array}$ & $\begin{array}{r}377 \\
\pm 37\end{array}$ & $\begin{array}{r}18.6 \\
\pm 1.5\end{array}$ & $\begin{array}{r}249 \\
\pm 34\end{array}$ & $\begin{array}{r}11.7 \\
\pm 1.6\end{array}$ & $\begin{array}{r}1.24 \\
\pm 0 \cdot 16\end{array}$ \\
\hline DNA-P+ve (11) & $\begin{array}{r}1432 \\
\pm 126\end{array}$ & $\begin{array}{r}65 \cdot 9 \\
\pm 2 \cdot 1\end{array}$ & $\begin{array}{r}820 \\
\pm 101\end{array}$ & $\begin{array}{r}35 \cdot 4 \\
\pm 2 \cdot 1\end{array}$ & $\begin{array}{r}617 \\
\pm 37\end{array}$ & $\begin{array}{r}30.9 \\
\pm 2.6\end{array}$ & $\begin{array}{r}290 \\
\pm 37\end{array}$ & $\begin{array}{r}14.0 \\
\pm 2.4\end{array}$ & $\begin{array}{r}401 \\
\pm 48\end{array}$ & $\begin{array}{r}18.6 \\
\pm 2.5\end{array}$ & $\begin{array}{r}254 \\
\pm 46\end{array}$ & $\begin{array}{r}10 \cdot 5 \\
\pm 1 \cdot 8\end{array}$ & $\begin{array}{r}1.25 \\
\pm 0 \cdot 14\end{array}$ \\
\hline DNA-P-ve (11) & $\begin{array}{r}1425 \\
\pm 122\end{array}$ & $\begin{array}{r}68 \cdot 3 \\
\pm 1 \cdot 8\end{array}$ & $\begin{array}{r}822 \\
\pm 121\end{array}$ & $\begin{array}{r}38.3 \\
\pm 2.2\end{array}$ & $\begin{array}{r}613 \\
\pm 20\end{array}$ & $\begin{array}{r}30 \cdot 6 \\
\pm 2.5\end{array}$ & $\begin{array}{r}329 \\
\pm 45\end{array}$ & $\begin{array}{r}17 \cdot 6 \\
\pm 2 \cdot 3\end{array}$ & $\begin{array}{r}308 \\
\pm 31\end{array}$ & $\begin{array}{r}16.2 \\
\pm 1.7\end{array}$ & $\begin{array}{r}241 \\
\pm 40\end{array}$ & $\begin{array}{r}12.7 \\
\pm 2.0\end{array}$ & $\begin{array}{r}1.39 \\
\pm 0.20\end{array}$ \\
\hline Controls (22) & $\begin{array}{r}1290 \\
\pm 90\end{array}$ & $\begin{array}{r}70 \cdot 0 \\
\pm 1 \cdot 0\end{array}$ & $\begin{array}{r}835 \\
\pm 55\end{array}$ & $\begin{array}{r}44.8 \\
\pm 0.8\end{array}$ & $\begin{array}{r}468 \\
\pm 34\end{array}$ & $\begin{array}{r}25 \cdot 8 \\
\pm 0 \cdot 7\end{array}$ & $\begin{array}{r}198 \\
\pm 21\end{array}$ & $\begin{array}{r}10 \cdot 5 \\
\pm 0 \cdot 4\end{array}$ & $\begin{array}{r}180 \\
\pm 22\end{array}$ & $\begin{array}{r}9.8 \\
\pm 0.4\end{array}$ & $\begin{array}{r}186 \\
\pm 18\end{array}$ & $\begin{array}{r}10 \cdot 1 \\
\pm 0 \cdot 7\end{array}$ & $\begin{array}{r}1.76 \\
\pm 0.05\end{array}$ \\
\hline
\end{tabular}

Note. $\mathrm{HBeAg}$ : Hepatitis B ' $\mathrm{e}$ ' antigen; DNA-P : DNA polymerase.

Data expressed as mean \pm 1 SEM. 
Table 3 Mononuclear cell subsets in acute viral hepatitis of different aetiology

\begin{tabular}{|c|c|c|c|c|c|c|c|c|c|c|c|c|c|}
\hline & \multicolumn{2}{|c|}{ OKT3 } & \multicolumn{2}{|c|}{ OKT4 } & \multicolumn{2}{|c|}{ OKT8 } & \multicolumn{2}{|c|}{$O K I a$} & \multicolumn{2}{|c|}{$O K M 1$} & \multicolumn{2}{|c|}{$H N K-1$} & \multirow{2}{*}{$\frac{O K T 4}{O K T 8}$} \\
\hline & No & $\%$ & No & $\%$ & No & $\%$ & No & $\%$ & No & $\%$ & No & $\%$ & \\
\hline \multicolumn{14}{|l|}{ HAV } \\
\hline $0-20$ days (3) & $\begin{array}{r}1129 \\
\pm 385\end{array}$ & $\begin{array}{r}70.6 \\
\pm 4.5\end{array}$ & $\begin{array}{r}531 \\
\pm 190\end{array}$ & $\begin{array}{r}32.7 \\
\pm 5.2\end{array}$ & $\begin{array}{r}622 \\
\pm 216\end{array}$ & $\begin{array}{r}39.1 \\
\pm 1.8\end{array}$ & $\begin{array}{r}154 \\
\pm 26\end{array}$ & $\begin{array}{r}10.3 \\
\pm 1.4\end{array}$ & $\begin{array}{r}183 \\
\pm 19\end{array}$ & $\begin{array}{r}13.1 \\
\pm 2.3\end{array}$ & $\begin{array}{r}303 \\
\pm 135\end{array}$ & $\begin{array}{r}19.1 \\
\pm 5.7\end{array}$ & $\begin{array}{r}0.85^{\mathrm{a}} \\
\pm 0.16\end{array}$ \\
\hline $21-50$ days (2) & $\begin{array}{r}1545 \\
\pm 299\end{array}$ & $\begin{array}{r}63.5 \\
\pm 1.2\end{array}$ & $\begin{array}{r}1083 \\
\pm 186\end{array}$ & $\begin{array}{r}41.8 \\
\pm 1.8\end{array}$ & $\begin{array}{r}503 \\
+222\end{array}$ & $\begin{array}{r}22.6 \\
\pm 2.3\end{array}$ & $\begin{array}{r}139 \\
\pm 28\end{array}$ & $\begin{array}{r}9.4 \\
+3.8\end{array}$ & $\begin{array}{r}468 \\
\pm 21\end{array}$ & $\begin{array}{r}15.8 \\
\pm 3.0\end{array}$ & $\begin{array}{r}295 \\
\pm 89\end{array}$ & $\begin{array}{r}12.8 \\
\pm 0.9\end{array}$ & $\begin{array}{r}1.87 \\
\pm 0.27\end{array}$ \\
\hline \multicolumn{14}{|l|}{ HBV } \\
\hline $0-20$ days (11) & $\begin{array}{r}1383 \\
\pm 138\end{array}$ & $\begin{array}{r}68.7 \\
\pm 1.8\end{array}$ & $\begin{array}{r}775 \\
\pm 115\end{array}$ & $\begin{array}{r}35.9 \\
\pm 2.3\end{array}$ & $\begin{array}{l}611^{\mathrm{b}} \\
\pm 36\end{array}$ & $\begin{array}{r}33.2 \\
\pm 2.8\end{array}$ & $\begin{array}{c}294^{\mathrm{c}} \\
\pm 38\end{array}$ & $\begin{array}{r}15.3 \\
\pm 2.4\end{array}$ & $\begin{array}{c}378^{\mathrm{a}} \\
\pm 39\end{array}$ & $\begin{array}{r}18.7 \\
\pm 2.1\end{array}$ & $\begin{array}{l}272^{\mathrm{d}} \\
\pm 52\end{array}$ & $\begin{array}{r}12 \cdot 2 \\
\pm 2 \cdot 1\end{array}$ & $\begin{array}{r}1 \cdot 19^{\mathrm{a}} \\
\pm 0.15\end{array}$ \\
\hline $21-50$ days (12) & $\begin{array}{r}1404 \\
\pm 119\end{array}$ & $\begin{array}{r}64.7 \\
\pm 1.9\end{array}$ & $\begin{array}{r}836 \\
\pm 97\end{array}$ & $\begin{array}{r}37.5 \\
1.6\end{array}$ & $\begin{array}{c}585^{\mathrm{d}} \\
\pm 35\end{array}$ & $\begin{array}{r}28.0 \\
\pm 1.8\end{array}$ & $\begin{array}{r}305^{\mathrm{c}} \\
\pm 46\end{array}$ & $\begin{array}{r}15 \cdot 7 \\
\pm 2 \cdot 1\end{array}$ & $\begin{array}{c}309^{b} \\
\pm 57\end{array}$ & $\begin{array}{r}16 \cdot 2 \\
\pm 2 \cdot 1\end{array}$ & $\begin{array}{l}222^{\mathrm{c}} \\
\pm 33\end{array}$ & $\begin{array}{r}11.4 \\
\pm 1.5\end{array}$ & $\begin{array}{r}1.42^{\mathrm{c}} \\
\pm 0.17\end{array}$ \\
\hline 51-90 days (3) & $\begin{array}{c}2028^{c} \\
\pm 384\end{array}$ & $\begin{array}{r}67 \cdot 3 \\
\pm 4 \cdot 4\end{array}$ & $\begin{array}{r}991 \\
\pm 182\end{array}$ & $\begin{array}{r}33.0 \\
\pm 1.6\end{array}$ & $\begin{array}{c}1037^{\mathrm{a}} \\
\pm 193\end{array}$ & $\begin{array}{r}34.7 \\
\pm 3.4\end{array}$ & $\begin{array}{c}342^{\mathrm{c}} \\
\pm 45\end{array}$ & $\begin{array}{r}11.6 \\
\pm 0.7\end{array}$ & $\begin{array}{r}293 \\
\pm 33\end{array}$ & $\begin{array}{r}10.2 \\
\pm 1.4\end{array}$ & $\begin{array}{r}595^{a} \\
\pm 153\end{array}$ & $\begin{array}{r}19.4 \\
\pm 1.6\end{array}$ & $\begin{array}{r}0.96^{\mathrm{a}} \\
\pm 0.04\end{array}$ \\
\hline $91-120$ days (5) & $\begin{array}{r}1221 \\
\pm 61\end{array}$ & $\begin{array}{r}70.0 \\
\pm 1.2\end{array}$ & $\begin{array}{r}789 \\
+42\end{array}$ & $\begin{array}{r}45 \cdot 2 \\
\pm 1 \cdot 1\end{array}$ & $\begin{array}{r}429 \\
\pm 28\end{array}$ & $\begin{array}{r}24.6 \\
\pm 0.8\end{array}$ & $\begin{array}{r}208 \\
\pm 53\end{array}$ & $\begin{array}{r}11.9 \\
\pm 2.9\end{array}$ & $\begin{array}{r}170 \\
\pm 38\end{array}$ & $\begin{array}{r}9.5 \\
\pm 1.7\end{array}$ & $\begin{array}{c}530^{\mathrm{a}} \\
\pm 98\end{array}$ & $\begin{array}{r}18.9 \\
\pm 1.3\end{array}$ & $\begin{array}{r}1.85 \\
\pm 0.09\end{array}$ \\
\hline non-A-non-B & & & & & & & & & & & & & \\
\hline $0-20$ days (4) & $\begin{array}{c}1814^{\mathrm{d}} \\
\pm 278\end{array}$ & $\begin{array}{r}65.4 \\
\pm 4.8\end{array}$ & $\begin{array}{r}1115 \\
\pm 218\end{array}$ & $\begin{array}{r}37 \cdot 1 \\
\pm 3.7\end{array}$ & $\begin{array}{r}784^{\mathrm{b}} \\
\pm 155\end{array}$ & $\begin{array}{r}26 \cdot 4 \\
\pm 3 \cdot 1\end{array}$ & $\begin{array}{r}537^{\mathrm{a}} \\
\pm 116\end{array}$ & $\begin{array}{r}19.3 \\
\pm 4.5\end{array}$ & $\begin{array}{r}600^{\mathrm{a}} \\
\pm 242\end{array}$ & $\begin{array}{r}19.4 \\
\pm 5.6\end{array}$ & $\begin{array}{c}324^{\mathrm{b}} \\
\pm 62\end{array}$ & $\begin{array}{r}11.3 \\
\pm 0.6\end{array}$ & $\begin{array}{r}1.42^{\mathrm{c}} \\
\pm 0.07\end{array}$ \\
\hline $21-50$ days (5) & $\begin{array}{c}1842^{\mathrm{c}} \\
\pm 246\end{array}$ & $\begin{array}{r}66.4 \\
\pm 2.8\end{array}$ & $\begin{array}{c}1180^{b} \\
\pm 115\end{array}$ & $\begin{array}{r}42.3 \\
\pm 2.4\end{array}$ & $\begin{array}{r}669 \\
+186\end{array}$ & $\begin{array}{r}24.7 \\
\pm 3.9\end{array}$ & $\begin{array}{c}399^{b} \\
\pm 86\end{array}$ & $\begin{array}{r}14.3 \\
\pm 1.6\end{array}$ & $\begin{array}{c}535^{\mathrm{a}} \\
\pm 94\end{array}$ & $\begin{array}{r}17.8 \\
\pm 3.6\end{array}$ & $\begin{array}{r}350^{c} \\
\pm 137\end{array}$ & $\begin{array}{r}11.2 \\
\pm 2.8\end{array}$ & $\begin{array}{r}2.01 \\
\pm 0.51\end{array}$ \\
\hline Controls (22) & $\begin{array}{l}1290^{\text {cd }} \\
\pm 90\end{array}$ & $\begin{array}{r}70.0 \\
\pm 1.0\end{array}$ & $\begin{array}{c}835^{\mathrm{b}} \\
\pm 55\end{array}$ & $\begin{array}{r}44.8 \\
\pm 0.8\end{array}$ & $\begin{array}{l}468^{\text {abd }} \\
\pm 34\end{array}$ & $\begin{array}{r}25.8 \\
\pm 0.7\end{array}$ & $\begin{array}{l}198^{\mathrm{abc}} \\
\pm 21\end{array}$ & $\begin{array}{r}10.5 \\
\pm 0.4\end{array}$ & $\begin{array}{l}180^{\mathrm{ab}} \\
\pm 22\end{array}$ & $\begin{array}{r}9.8 \\
\pm 0.4\end{array}$ & $\begin{array}{c}186^{\text {abc }} \\
\pm 18\end{array}$ & $\begin{array}{r}10.1 \\
\pm 0.7\end{array}$ & $\begin{array}{r}176^{\text {ac }} \\
\pm 0.05\end{array}$ \\
\hline
\end{tabular}

P values a: $\mathrm{p}<0.001 ; \mathrm{b}: \mathrm{p}<0.01 ; \mathrm{c}: \mathrm{p}<0.02 ; \mathrm{d}: \mathrm{p}<0.05$.

Data are expressed as mean \pm SEM.
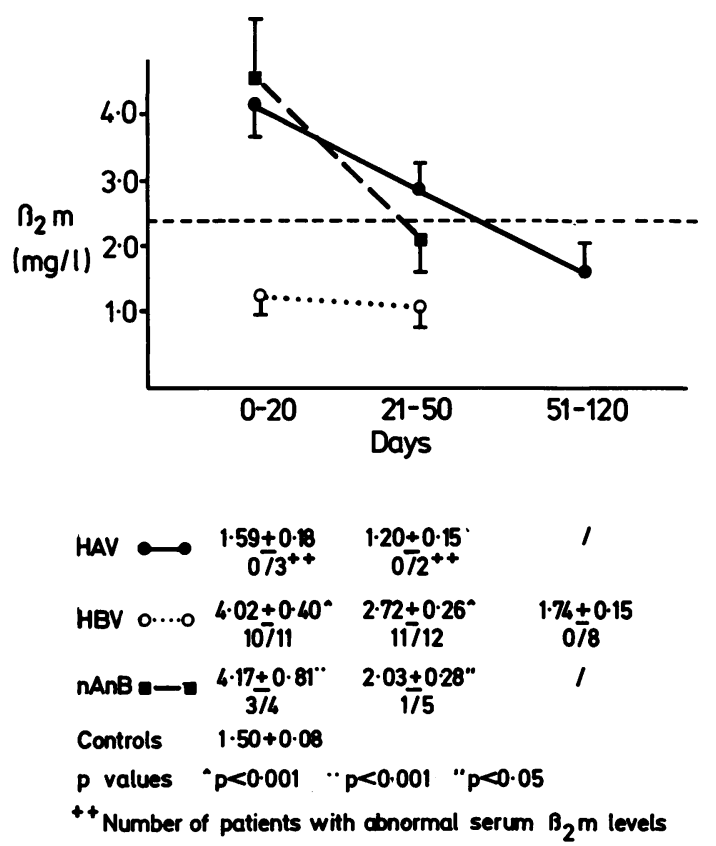

Fig. 2 Serum $\beta_{2}$ microglobulin concentrations as a function of time after clinical onset in patients with acute viral hepatitis of different aetiology. toxic $T$ cell ratio, with a significant increase in the OKT8 positive subset in acute type $B$ and non-Anon- $B$ hepatitis as described in other viral diseases. ${ }^{12}$ This altered ratio persisted in type $B$ for a long time until HBsAg antibody became detectable, but soon returned to normal in type $A$ and non- $A$ non- $\mathrm{B}$ hepatitis. Because the immune response is

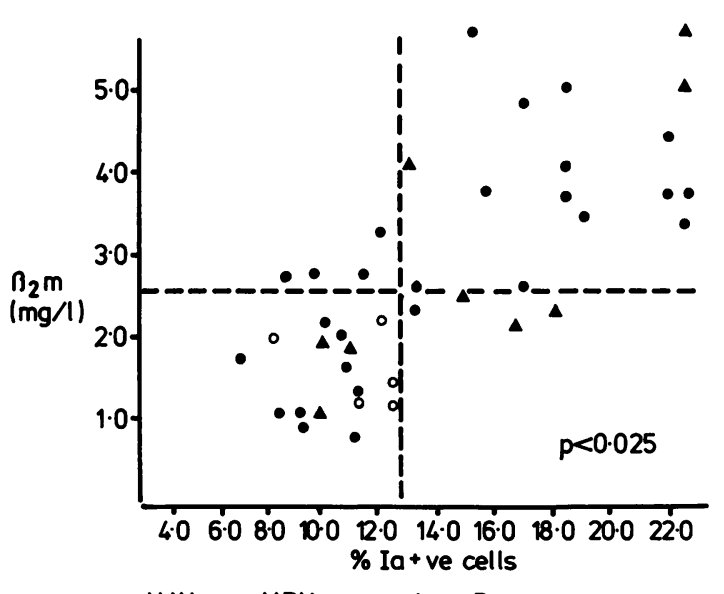

HAV O HBV • non A non B $\triangle$

Fig. 3 Relationship between $\beta_{2}$ microglobulin concentrations and Ia positive cells in acute viral hepatitis patients. 
considered a likely pathogenetic determinant in HBV infection, host immunoregulatory mechanisms might be important in recovery from acute viral hepatitis and in perpetuating hepatocyte injury in chronic liver disease. Suppressor cell function studies in acute and chronic HBV infection have produced conflicting findings. ${ }^{13-17}$ These might be explained by differences in selection of patients and controls and in suppressor cell assay methods. Kakumu et al, ${ }^{18}$ however, have reported an increased suppression of both IgC and IgM synthesis by PWM stimulated peripheral blood mononuclear cells in patients convalescent from acute type B hepatitis. Therefore, although the OKT8 positive cell population includes both suppressor and cytotoxic $\mathrm{T}$ cells, our data suggest that the increase in OKT8 positive cells found during HBs antigenaemia may reflect an increase in suppressor cell influence which might limit the immune response to HBV antigens. The immunoregulatory imbalance returns to normal with complete clinical recovery from acute HBV infection but persisted in chronic carriers, as previously described. ${ }^{45}$ In patients with chronic HBV infection, however, the altered ratio was based primarily on a reduction of the helper (OKT4 positive) subset of lymphoid cells ${ }^{4}{ }^{19}$ and not on increased OKT8 positive cells number as observed in acute hepatitis. Therefore, in the majority of acute hepatitis the altered ratio is due to an increase and not a decrease in the whole $T$ cell population. Recently, Fahey et $a l^{20}$ suggested that homosexual patients with acquired immunodeficiency syndrome (AIDS) and pneumonia or Kaposi's sarcoma (all showing decreased OKT4 positive cells) had a poor prognosis, whereas healthy homosexual men with an expanded OKT8 positive subset, probably reflecting viral infections from cytomegalovirus, HBV or widespread exposure to other infectious agents, had an uncertain but probably better prognosis.

Additional studies on suppressor and helper $\mathrm{T}$ cell functions specific for HBV antigens may lead to a better comprehension of the immunoregulatory mechanisms involved in this disease. Moreover, the finding that the subpopulation of inducer cells responsible for maximal helper activity for B cell differentiation is restricted to a minor subset of OKT4 positive cells, ${ }^{21} 22$ and that the induction of suppression may require OKT4 positive cells ${ }^{23}$ further complicates the interpretation of the findings.

The increased numbers of M1 and HNK-1 cells in acute type $B$ and non-A-non-B hepatitis, even considering patients' age,$^{24}$ suggest the need for further investigations to evaluate the possible role of $\mathrm{K}$ and NK cells in acute viral hepatitis. The persistence of raised HNK-1 cell numbers during recovery from type $B$ hepatitis, when anti-HBs becomes detectable, is consistent with the finding of increased cytotoxic activity by NK cells against an HBsAg secreting hepatoma cell line in convalescent hepatitis B patients. ${ }^{25}$ These data support the hypothesis that NK cells play a role in the host defence responses to $\mathrm{HBV}$ infection.

The normal peripheral blood mononuclear cell populations and behaviour of $T$ cell subsets in patients with acute type $\mathrm{A}$ hepatitis are consistent with the view that immune mechanisms are not involved in the pathogenesis of hepatitis A liver injury. On the other hand, the significant alterations in immunoregulatory cells in the early phase of acute type non-A-non-B hepatitis could reflect the involvement of immunological mechanisms in this disease.

We have shown that serum $\beta_{2}$ m concentrations were different in the three types of viral hepatitis as shown by Beorchia et al ${ }^{26}$ normal values were found in hepatitis A cases, significantly raised concentrations were observed in hepatitis $B$, and non-A-non-B. Bernier and Fanger ${ }^{27}$ first demonstrated that $\beta_{2} \mathrm{~m}$ was mainly a product of $T$ lymphocytes as it was produced by PHA but not by PWM stimulated peripheral blood lymphocytes. This has recently been confirmed using a different system. ${ }^{6}$ It is concluded that $\beta_{2} \mathrm{~m}$ release reflects primarily $T$ cell activation. The increase in serum $\beta_{2} \mathrm{~m}$ concentrations in our patients was due to augmented production and not decreased renal catabolism: neither proteinuria nor any evidence of renal insufficiency were present. Serum $\beta_{2} \mathrm{~m}$ concentrations increased only in acute hepatitis where immunological mechanisms are suspected to be involved, and the correlation between $\beta_{2} \mathrm{~m}$ and OKIa positive cell number suggests that activated lymphocytes and not liver cell necrosis is responsible.

We are indebted to Dr A L W F Eddleston, Liver Unit, King's College, London, for his valuable advice.

\section{References}

1 Chisari FV, Routenberg TA, Anderson DS, Edgington TS. Cellular immune reactivity in HBV-induced liver disease. In: Vyas GN, Cohen SN, Schmid R, eds. Viral hepatitis. Philadelphia: Franklin Institute Press, 1978.

2 Mieli Vergani G, Vergani D, Partmann B et al. Lymphocyte cytotoxicity to autologous hepatocytes in HBsAg positive chronic liver disease. Gut 1982; 23: 1029-36.

3 Reinherz EL, Rubinstein A. Geha RS, Strelkauskas 
AJ, Rosen FS, Schlossman SF. Abnormalities of immunoregulatory $\mathrm{T}$ cells in disorders of immune function. N Engl J Med 1979; 301: 1018.

4 Thomas HC, Bown D, Routhier G et al. Inducer and suppressor $\mathrm{T}$ cells in hepatitis $\mathrm{B}$ virus-induced liver disease. Hepatology 1982; 2: 202.

5 Barnaba V, Zaccari C, Levrero M, Ruocco G, Balsano F. Immunoregulatory T cells in HBV induced chronic liver disease as defined by monoclonal antibodies. Clin Immunol Immunopathol 1983; 26: 83.

6 Kin K, Kasahara T, Itoh Y, Sakurabayaschi I, Kawai T, Morita $\mathrm{M}$. $\beta_{2}$ microglobulin production by highly purified human $T$ and $B$ lymphocytes in cell culture stimulated with various mitogens. Immunology 1979; 36: 47.

7 Beorchia S, Vincent C, Revillard JP, Trepo C. Elevation of serum $\beta_{2}$ microglobulin in liver disease. Clin Chim Acta 1981; 109: 245.

8 Hallgren R. Serum $\beta_{2}$ microglobulin in liver disease. Scand J Clin Lab Invest 1979; 39: 441.

9 Kaplan PM, Greenman RL, Gerin JL, Purcell RH, Robinson WS. DNA polymerase associated with human hepatitis B e antigen. J Virol 1973; 12: 995.

10 Zanetti AR, Ferroni P. Presence of $\mathrm{HBeAg}$, DNA polymerase activity, Dane particles in different categories of HBsAg carriers and evidence of hepatitis type B infection in their family contacts. Boll Ist Sieroter Milan 1977; 56: 79.

11 Boyum A. Separation of leucocytes from blood and bone marrow. Scand J Clin Lab Invest 1968; 21: 77.

12 Carney WP, Rubin RH, Hoffman RA, Hansen WP, Healey K, Hirsch MS. Analysis of T lymphocyte subsets in cytomegalovirus mononucleosis. J Immunol 1981; 126: 2114.

13 Chisari FV, Castle KL, Xavier C, Anderson DS. Functional properties of lymphocytes subpopulations in hepatitis B virus infection. I. Supressor cell control of T lymphocyte responsiveness. J Immunol 1981; 126: 38.

14 Alexander GJM, Nouri K, Hegarty J, Eddleston ALWF, Williams R. Relationship of T cell subsets to suppressor cell function in chronic liver disease. [Abstract] Gut 1982; 23: A461.

15 Kerlin P, Nies KM, Tong MJ. Unimpaired B cell function and $T$ cell regulation of immunoglobulin synthesis in patients with chronic hepatitis B virus infection. Clin Immunol Immunopathol 1982; 25: 149.

16 Tremolada F, Fattovich G, Panebianco G, Ongaro G,
Realdi G. Suppressor cell activity in viral and non-viral chronic active hepatitis. Clin Exp Immunol 1980; 40: 89.

17 Ortona L, Laghi V, Cauda R, Tamburrini E, Nervo P. Suppressor cell activity in the course of type B acute viral hepatitis. IRCS 1982; 10: 745.

18 Kakumu S, Yata K, Kashio T. Immunoregulatory T cell function in acute and chronic liver disease. Gastroenterology 1980; 79: 613.

19 Barnaba V, Musca A, Cordova C et al. Relationship between $\mathrm{T}$ cell subsets and suppressor cell activity in chronic hepatitis B virus (HBV) infection. Clin Exp Immunol 1983; 53: 281.

20 Fahey JL, Detels R, Gottlieb M. Immune cell augmentation (with altered T subset ratio) is common in healthy homosexual men. $N$ Engl J Med 1983; 308: 842.

21 Corte G, Mingari MC, Moretta A, Damiani G, Moretta L, Bargellesi A. Human T cell subpopulation defined by a monoclonal antibody. I. A small subset is responsible for proliferation to allogeneic cells or to soluble antigens and for helper activity for B cell differentiation. J Immunol 1982; 128: 16.

22 Reinherz EL, Morimoto C, Fitsgerald KA, Hussey RE, Daley JF, Scholssman SF. Heterogeneity of human $\mathrm{T}^{+}$inducer $\mathrm{T}$ cells defined by a monoclonal antibody that delineates two functional subpopulations. J Immunol 1982; 128: 463.

23 Thomas Y, Rogozinski L, Frigoyen $\mathrm{OH}$ et al. Functional analysis of human $\mathrm{T}$ cell subsets defined by monoclonal antibodies. J Exp Med 1981; 154: 459.

24 Abo T, Cooper MD, Balch CM. Postnatal expansion of the natural niller and killer cell population in humans identified by the monoclonal HNK-1 antibody. $J$ Exp Med 1982; 155: 321.

25 Chin TW, Hollinger FB, Rich RR, Troisi CL, Dreesman GR, Melnick JL. Cytoxicity by NK-like cells from hepatitis B immune patients to a human hepatoma cell line secreting HBsAg. J Immunol 1983; 130: 173 .

26 Beorchia S, Trepo C, Vincent C, Revillard JP, Brette $\mathrm{R}$. Interêt prognostique et pathogénique de l'élévation de la $\beta_{2}$ microglobulin dans les hépatites aigues et chroniques. Gastroenterol Clin Biol 1982; 6: 679.

27 Bernier GM, Fangier MW. Synthesis of $\beta_{2}$ microglobulin by stimulated lymphocytes. J Immunol 1972; 109: 407. 